\title{
Hurricane Sandy Washover Deposits on Southern Long Beach Island, New Jersey
}

By James M. Bishop, Bruce M. Richmond, Nicholas J. Zaremba, Brent D. Lunghino, and Haunani H. Kane

Open-File Report 2016-1090

U.S. Department of the Interior

U.S. Geological Survey 


\title{
U.S. Department of the Interior \\ SALLY JEWELL, Secretary
}

\author{
U.S. Geological Survey \\ Suzette M. Kimball, Director
}

U.S. Geological Survey, Reston, Virginia: 2016

For more information on the USGS—-the Federal source for science about the Earth, its natural and living resources, natural hazards, and the environment-visit http://www.usgs.gov/ or call 1-888-ASK-USGS (1-888-275-8747).

For an overview of USGS information products, including maps, imagery, and publications, visit http://store.usgs.gov/.

Any use of trade, firm, or product names is for descriptive purposes only and does not imply endorsement by the U.S. Government.

Although this information product, for the most part, is in the public domain, it also may contain copyrighted materials as noted in the text. Permission to reproduce copyrighted items must be secured from the copyright owner.

Suggested citation:

Bishop, J.M., Richmond, B.R., Zaremba, N.J., Lunghino, B.D., and Kane, H.K., 2016, Hurricane Sandy washover deposits on southern Long Beach Island, New Jersey: U.S. Geological Survey Open-File Report 2016-1090, 14 p., http://dx.doi.org/10.3133/ofr20161090. 


\section{Acknowledgments}

Financing for this study was provided by the Disaster Relief Appropriations Act of 2013, utilizing the Department of the Interior Hurricane Sandy supplemental funding. The authors thank Maziet Cheseby (Oregon State University College of Earth, Ocean, and Atmospheric Sciences) for assistance with computed tomography (CT) scanning and Virginia Rettig (U.S. Fish and Wildlife Service) for supporting our field work in the Edwin B. Forsyth Wildlife Refuge.

The authors also thank Nathaniel Plant and Christopher Smith (USGS) for support and thoughtful scientific input during this study, Kathryn Smith (USGS) for help in the field, and Julie Bernier (USGS) for reviewing a draft of this report. 


\section{Contents}

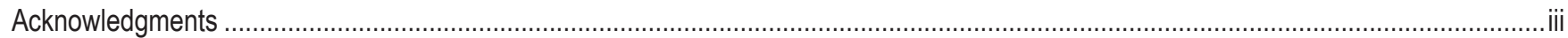

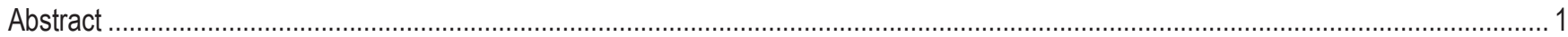

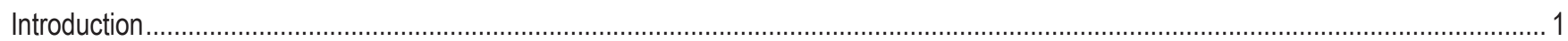

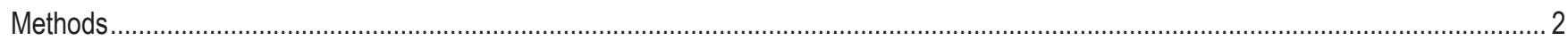

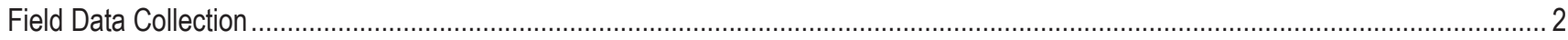

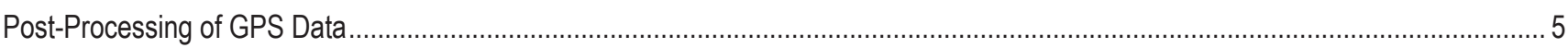

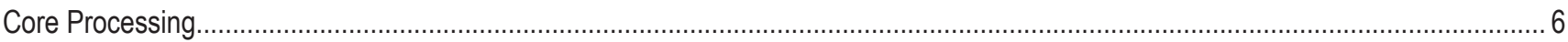

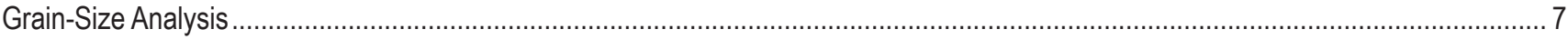

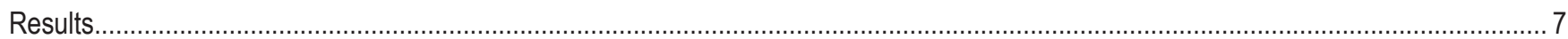

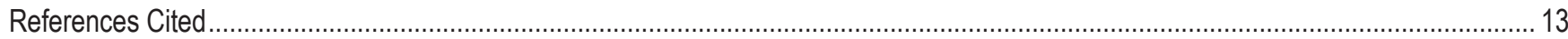

\section{Figures}

1. (A) Map showing the path of the center of Hurricane Sandy and the extent of hurricane force winds; $(B)$ Large-scale inset map showing southern Long Beach Island, New Jersey.....

2. Aerial photographs showing locations where push cores and Russian cores were collected and trenches in five sampling transects, southern Long Beach Island, New Jersey......

3. (A) Photograph showing trench 3, transect 3, with white sand deposited by Hurricane Sandy above the dark pre-Hurricane Sandy marsh surface; (B) post-Hurricane Sandy imagery (November 6, 2012) with washover fan visible; and (C) pre-Hurricane Sandy imagery (March-April 2012) with the pre-hurricane marsh surface visible.

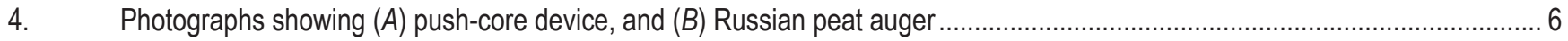

5. (A) Orthoimagery collected November 6, 2012, showing Hurricane Sandy washover deposits. Note the sharp outlines of the different washover fans. (B) Orthoimagery collected in September 2013 showing the sediment reworking that occurred in the time since Hurricane Sandy sediments were deposited

6. Photograph and CT scan of push core PC13 showing the massive deposit from Hurricane Sandy at the bottom of the core at a depth of 20-31 centimeters

7. Example of coarsening upward sequence exhibited in sediment above pre-hurricane surface in push core BH15-PC12 ..........11

8. Core log for Russian peat auger BH15-RC06, Long Beach Island, New Jersey ................................................................. 12 


\section{Conversion Factors}

\begin{tabular}{|c|c|c|}
\hline Multiply & By & To obtain \\
\hline \multicolumn{3}{|c|}{ Length } \\
\hline micrometer $(\mu \mathrm{m})$ & 0.00003937 & inch (in.) \\
\hline centimeter $(\mathrm{cm})$ & 0.3937 & inch (in.) \\
\hline millimeter $(\mathrm{mm})$ & 0.03937 & inch (in.) \\
\hline meter $(\mathrm{m})$ & 3.281 & foot $(\mathrm{ft})$ \\
\hline kilometer (km) & 0.6214 & mile (mi) \\
\hline kilometer (km) & 0.5400 & mile, nautical (nmi) \\
\hline meter $(\mathrm{m})$ & 1.094 & yard (yd) \\
\hline \multicolumn{3}{|c|}{ Volume } \\
\hline liter (L) & 33.82 & ounce, fluid (fl. oz) \\
\hline liter (L) & 2.113 & $\operatorname{pint}(\mathrm{pt})$ \\
\hline liter (L) & 1.057 & quart (qt) \\
\hline liter $(\mathrm{L})$ & 0.2642 & gallon (gal) \\
\hline \multicolumn{3}{|c|}{ Mass } \\
\hline $\operatorname{gram}(\mathrm{g})$ & 0.03527 & ounce, avoirdupois (oz) \\
\hline
\end{tabular}

\section{Datums}

Vertical coordinate information is referenced to the North American Vertical Datum of 1988 (NAVD88).

Horizontal coordinate information is referenced to the North American Datum of 1983 (NAD83).

Elevation, as used in this report, refers to distance above the vertical datum.

\section{Supplemental Information}

Data used in this report are available as an accompanying data release (Bishop and others, 2016): http://dx.doi.org/10.5066/F7PKOD7S. 


\begin{tabular}{ll} 
Abbreviations \\
gdb & Esri file geodatabase \\
18N & Zone 18 North \\
BIWC & Barrier Island and Estuarine Wetland Physical Change Assessment \\
CORS & continuously operating reference station \\
CT & computed tomography \\
DGPS & differential global positioning system \\
DICOM & Digital Imaging and Communications in Medicine \\
FAN & Field Activity Number \\
FDGC & Federal Geographic Data Committee \\
GIS & geographic information system \\
GPR & ground-penetrating radar \\
GPS & global positioning system \\
HS & Hurricane Sandy \\
ID & identification \\
JPEG & Joint Photographic Experts Group \\
KML & Keyhole Markup Language \\
lidar & light detection and ranging \\
mL & milliliter \\
$n$ & number of samples used in mean \\
NMEA & National Marine Electronics Association \\
NOAA & National Oceanic and Atmospheric Association \\
PCMSC & Pacific Coastal and Marine Science Center (USGS) \\
PNG & portable network graphics \\
PVC & polyvinyl chloride \\
SPCMSC & St. Petersburg Coastal and Marine Science Center (USGS) \\
TIFF & Tagged Image File Format \\
USGS & U.S. Geological Survey \\
UTM & Universal Transverse Mercator \\
& \\
\hline
\end{tabular}




\title{
Hurricane Sandy Washover Deposits on Southern Long Beach Island, New Jersey
}

\author{
By James M. Bishop , ${ }^{1}$ Bruce M. Richmond, ${ }^{1}$ Nicholas J. Zaremba, ${ }^{1}$ Brent D. Lunghino, ${ }^{1}$ and Haunani H. Kane ${ }^{2}$
}

\begin{abstract}
Sedimentologic and topographic data from Hurricane Sandy washover deposits were collected from southern Long Beach Island, New Jersey, in order to document changes to the barrier-island beaches, dunes, and coastal wetlands caused by Hurricane Sandy and subsequent storm events. These data will provide a baseline dataset for use in future coastal change descriptive and predictive studies and assessments. The data presented here were collected as part of the U.S. Geological Survey's Barrier Island and Estuarine Wetland Physical Change Assessment Project (http://coastal.er.usgs.gov/sandy-wetland-assessment/), which aims to assess ecological and societal vulnerability that results from long- and short-term physical changes to barrier islands and coastal wetlands. This report describes data that were collected in April 2015, approximately 2 $\frac{1}{2}$ years after Hurricane Sandy's landfall on October 29, 2012. During the field campaign, washover deposits were photographed and described, and sediment cores, sediment samples, and surface-elevation data were collected. Data collected during this study, including sample locations and elevations, core photographs, computed tomography scans, descriptive core logs, sediment grain-size data, and accompanying Federal Geographic Data Committee metadata, are available in the associated U.S. Geological Survey data release (Bishop and others, 2016; http://dx.doi.org/10.5066/F7PK0D7S).
\end{abstract}

\section{Introduction}

Sedimentologic data from Hurricane Sandy (HS) washover deposits on Long Beach Island, New Jersey, were collected in order to characterize and document the geological impact to barrier islands from the storm. HS was one of the deadliest and most costly hurricanes to make landfall in the United States, impacting the entire U.S. eastern seaboard from Florida to Maine and as far inland as Michigan. The most substantial damage occurred to the mid-Atlantic States, particularly New Jersey and New York, where a combination of storm surge, wave runup, heavy rainfall, and strong winds resulted in an estimated $\$ 79$ billion in damage (Henry and others, 2013). Along Long Beach Island, New Jersey, storm-induced erosion, overwash, and inundation re-distributed sediment and damaged coastal infrastructure. The purpose of this report is to provide a baseline dataset for future sedimentological and coastal change descriptive and predictive studies and assessments.

HS made landfall as an extratropical cyclone on October 29, 2012, near Brigantine, New Jersey. While hurricane force wind speeds did occur along the New Jersey coast, the most notable characteristic of the hurricane was the enormous wind swath, which extended 2,000 kilometers $(\mathrm{km})$ along the coastline. The large wind swath combined with the nearly orthogonal angle at which the hurricane approached the coast resulted in high storm surges that affected extensive portions of the U.S. eastern seaboard (Blake and others, 2013). At the Little Egg Inlet tide gage (USGS 01409335), approximately $2 \mathrm{~km}$ from southern Long Beach

\footnotetext{
${ }^{1}$ U.S. Geological Survey.
}

${ }^{2}$ University of Hawaii at Manoa, Department of Geology and Geophysics. 
Island, water levels peaked at 2 meters (m) higher than normal high tide levels. New Jersey barrier islands north of Brigantine were almost completely flooded and in many cases breached due to the combination of large storm surge and Atlantic surf (Blake and others, 2013).

The U.S. Geological Survey (USGS) is documenting physical changes to coastlines that result from hurricanes in order to incorporate such information into storm-induced coastal change predictive models. The data described in this report were collected as part of the Barrier Island and Estuarine Wetland Physical Change Assessment (BIWC) Project. The goal of the BIWC Project is to assess ecological and societal vulnerability that results from long- and short-term changes to barrier islands and coastal wetlands. This report, in combination with similar studies conducted at Assateague Island, Maryland (Julie Bernier, U.S. Geological Survey, written commun., 2016), and Fire Island, New York (Seanpaul La Selle, U.S. Geological Survey, written commun., 2016), will provide data that will contribute to updating coastal change models which will help predict physical changes that occur to barrier islands and coastal wetlands as a result of storms.

Field work for this study was conducted during April 7-14, 2015, approximately $2 \frac{1}{2}$ years after HS made landfall. Sediment data were collected from the southern end of Long Beach Island near the town of Beach Haven, within the Holgate unit of the Edwin B. Forsythe National Wildlife Refuge, approximately $20 \mathrm{~km}$ northeast of where the center of the hurricane eye made landfall (fig. 1). Long Beach Island is a $30-\mathrm{km}$-long barrier island along the eastern coast of New Jersey, and the Holgate unit of the wildlife refuge is on the southernmost $5 \mathrm{~km}$ of the island. Because the Holgate unit of the wildlife refuge remains undeveloped, it provides an excellent place to study storm-related coastal change in a natural setting. This report documents sediment core data that were collected during USGS Field Activity Number (FAN) 2015-611-FA. Data presented include descriptive core logs, core photographs, computed tomography (CT) scans, results of sediment analyses, and elevations, all of which are available in the associated USGS data release (Bishop and others, 2016; http://dx.doi.org/10.5066/F7PK0D7S). Ground-penetrating radar (GPR) data were also collected during the course of the current study.

\section{Methods}

\section{Field Data Collection}

Scientists from the USGS Pacific Coastal and Marine Science Center (PCMSC), the USGS St. Petersburg Coastal and Marine Science Center (SPCMSC), and students from the University of Hawaii conducted field work from April 7 to 14, 2015, during which time 49 trenches were dug, documented, and photographed. In addition, 33 sediment cores, 12 sediment source grab samples, and differential global positioning system (DGPS) elevations were collected. Sampling locations were chosen after analyzing pre- and post-storm aerial imagery (pre-storm, March-April 2012, New Jersey Office of Information Technology, Office of Geographic Information Systems, 2013; post-storm, November 6, 2012, National Oceanic and Atmospheric Administration, 2012) and lidar data (pre-storm, October 26, 2012, post-storm, November 1 and 5 , 2012, Wright and others, 2014) to identify areas of Long Beach Island that were overwashed by HS. Washover deposits from HS were documented along five transects that were oriented roughly parallel to the long axis of the washover fan (that is, parallel to the inferred overwash flow direction) (fig. 2). Sediment cores were collected and trenches were dug periodically along each of the transects. In addition to the five washover transects, trenches were dug and sediment cores were collected from areas that did not contain washover deposits from HS in order to document and compare sedimentologic characteristics of non-HS deposits. 


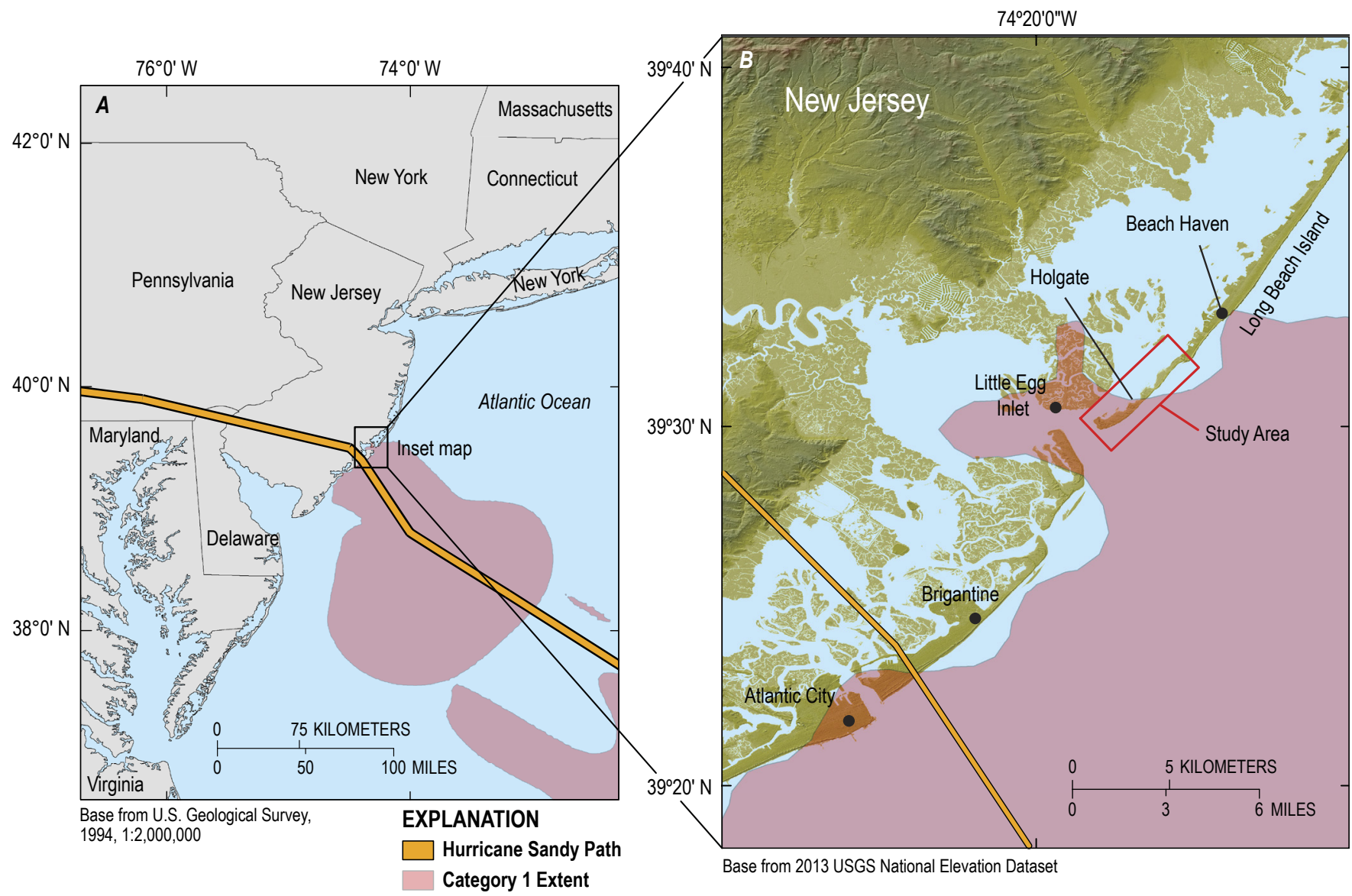

Figure 1. (A) Map showing the path of the center of Hurricane Sandy and the extent of hurricane force winds. Hurricane force wind extent and hurricane path from the National Oceanic and Atmospheric Administration, National Hurricane Center (2015). (B) Large-scale inset map showing southern Long Beach Island, New Jersey.

Sample locations were recorded at the time of collections by using Garmin GPSmap 60CSx handheld receivers. At most sampling locations, position and elevation data were also recorded by using an Ashtech Proflex DGPS receiver and a geodetic antenna. Field setup consisted of a rover receiver collecting GPS data at a frequency of 1 second. The receiver was placed within a backpack and connected to the antenna; data were recorded to a flash drive. The antenna was mounted on a metal pole with a spike on the bottom, the spike was pushed into the ground, and the height of the GPS antenna above the ground was measured and recorded when the system was set up. Each site was occupied from 5 to 45 minutes, and the start and stop times of each occupation site were recorded.

Trenches were dug such that the walls were roughly parallel to the long axis of the washover fan (parallel to the inferred overwash flow direction). Each trench was photographed and described, with special attention paid to identifying the depth of the pre-HS surfaces where possible. At some locations, the pre-HS surface, identified by using pre-HS aerial imagery, was a brown, rooted peat or soil that has been overlain by a light-colored sand (fig. 3). In these cases, identification of the pre-HS surface in the field was obvious. In other locations, a shallow water table resulted in collapse of the trench walls before reaching the pre-HS surface.

Cores were collected by using either a 7.62-centimeter $(\mathrm{cm})(3$-inch) diameter push-core device or a 5.2-cm-diameter, 50-cm-long Russian peat auger (fig. 4). In general, push cores were composed of shallow sediment that occurred above the groundwater table. The Russian peat augers were able to sample sediment 


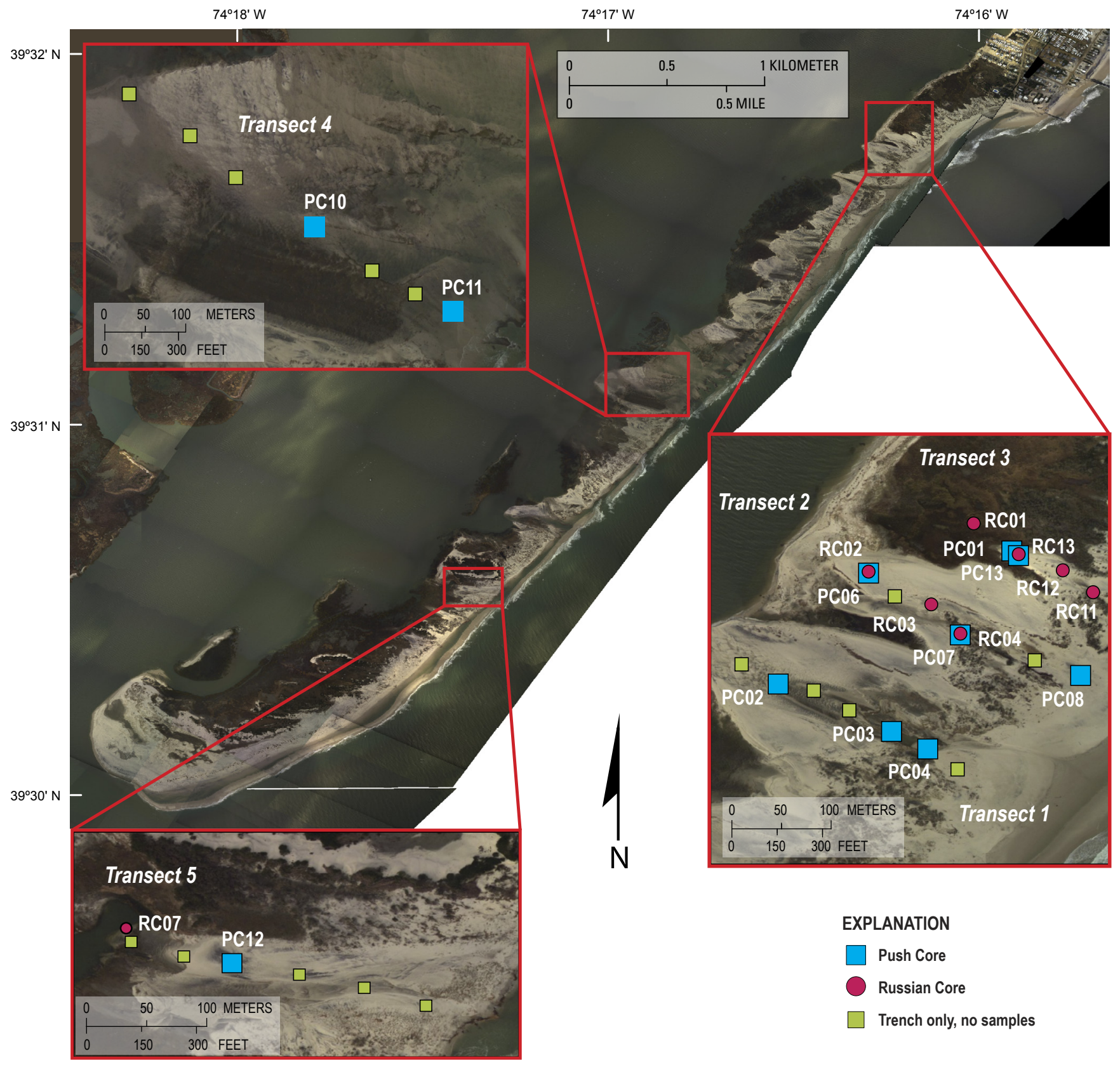

Figure 2. Aerial photographs showing locations where push cores and Russian cores were collected and trenches in five sampling transects, southern Long Beach Island, New Jersey. Off-transect samples not shown. Orthoimagery is mosaicked from data collected on November 6, 2012, shortly after Hurricane Sandy made landfall. Imagery courtesy of the National Oceanic and Atmospheric Administration (2012).

within ponds or below the water table. In total, 13 push cores and 20 Russian cores were collected. At six of the sites, multiple Russian cores were collected, each penetrating to different depths. Push cores were capped and sealed upon extraction, and the location and core ID were recorded. A north arrow was marked on the push cores in order to orient them for CT scanning and laboratory analysis (described below). Russian cores were transferred to polyvinyl (PVC) tubes that had been split lengthwise. Then the tubes were wrapped in plastic and taped. Location and core IDs were recorded, but due to the nature of Russian core extraction, orientation was uncertain and not recorded. Bulk sediment grab samples weighing between 5 and 30 grams were collected from potential sediment sources and analyzed for grain size. 

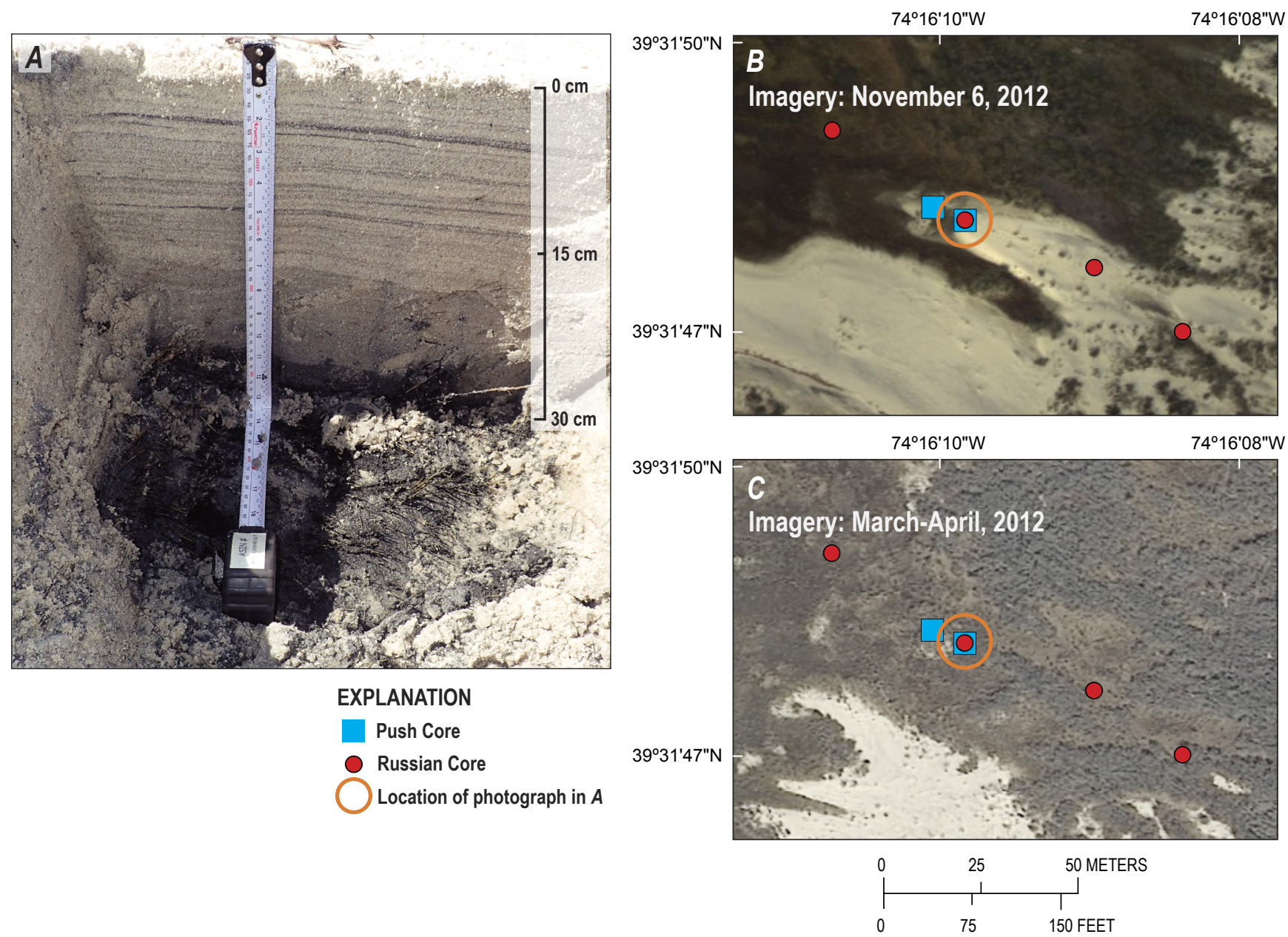

Figure 3. (A) Photograph showing trench 3, transect 3, with white sand deposited by Hurricane Sandy above the dark pre-Hurricane Sandy marsh surface; $(B)$ post-Hurricane Sandy imagery (November 6, 2012) with washover fan visible; and $(C)$ pre-Hurricane Sandy imagery (March-April 2012) with the pre-hurricane marsh surface visible.

\section{Post-Processing of GPS Data}

The global positioning system (GPS) data collected during USGS FAN 2015-611-FA were differentially corrected by post-processing using continuously operating reference stations (CORS) NJGT, NJOC, and NJCM located approximately 23,50 , and $65 \mathrm{~km}$, respectively, away from the study location. It was necessary for multiple CORS to be used during post-processing because some of the CORS were not in operation during the entire time of data collection. Data for the CORS used during processing of the GPS data were obtained from the National Oceanic and Atmospheric Administration (NOAA, 2015). The CORS coordinates were imported into GrafNav, version 8.4 (NovAtel Waypoint Product Group), and the data from the rover GPS (the GPS unit used to collect data at each sample site) were post-processed to the concurrent CORS session. The position data were then exported from GrafNav. Vertical GPS accuracies ranged from 13 millimeters (mm) (25-km CORS) to $30 \mathrm{~mm}$ (65-km CORS), and horizontal GPS accuracies ranged from $5 \mathrm{~mm}$ (25-km CORS) to $10 \mathrm{~mm}$ (65-km CORS). 

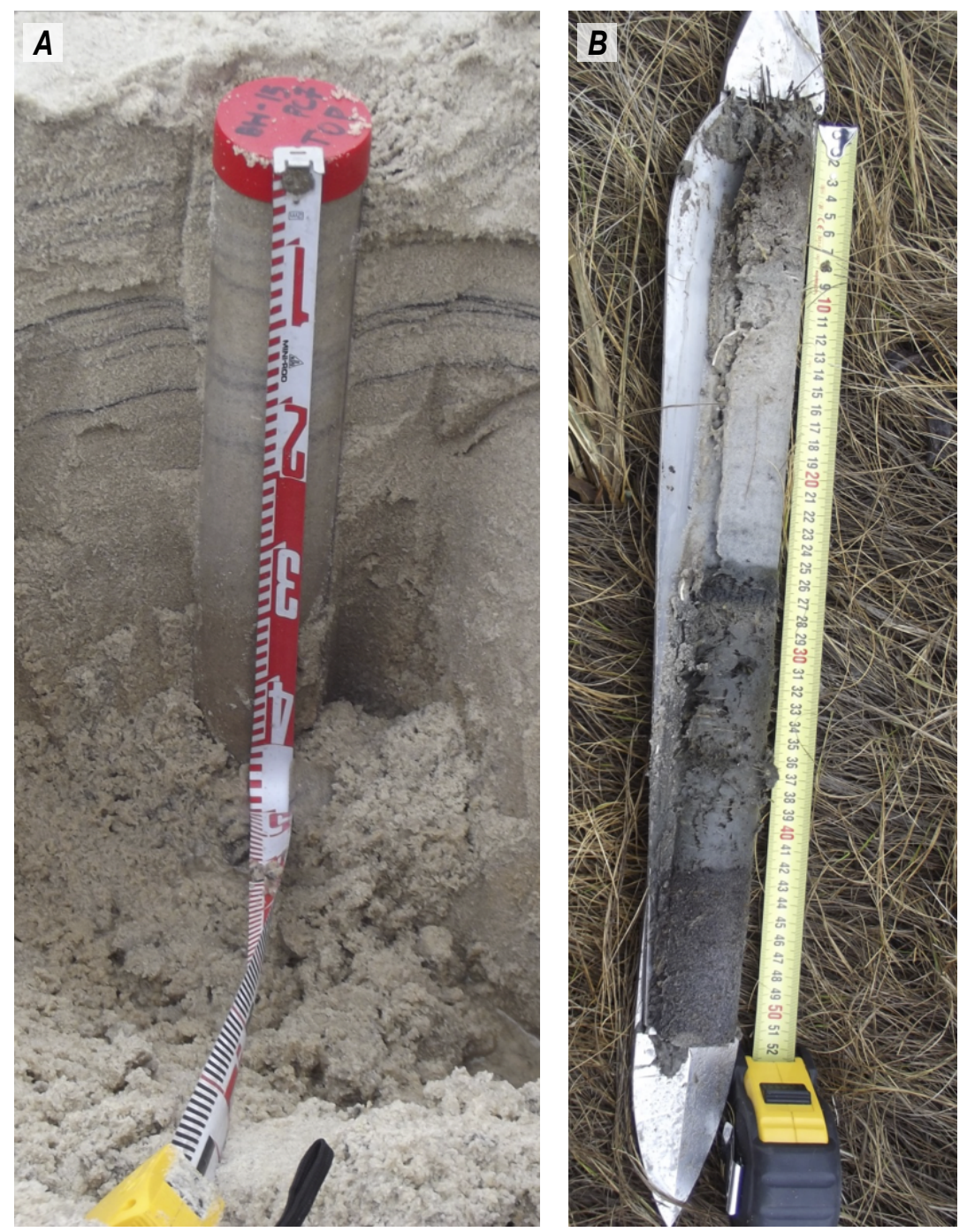

Figure 4. Photographs showing $(A)$ push-core device, and $(B)$ Russian peat auger.

\section{Core Processing}

Sediment cores were shipped from the field location directly to the College of Earth, Ocean, and Atmospheric Sciences at Oregon State University where they were imaged using CT density scans. The CT scans enable 3-dimensional imaging of the core densities and reveal internal sedimentary structure. Scans of each core were acquired by using a Toshiba Aquilon 64 Slice and were collected at 120 peak kilovoltage and 200 milliamps and a pitch of 0.5 second (100 milliampere-seconds). For visualization purposes, the resulting images were processed with a "bone" algorithm to generate coronal images every 2 mm across the core. Push cores were oriented in the CT scanner with the north arrow facing up, towards the ceiling. Russian cores were oriented such that the flat portion of the half-cylinder core was facing upwards. Resulting images are referred to as either coronal or sagittal. Coronal images view the core perpendicular to the horizontal plane, and sagittal images view the core perpendicular to the vertical plane. After CT scanning was complete, cores were shipped to the PCMSC. At the PCMSC, raw images were edited by using OsiriX, software dedicated to editing Digital Imaging and Communications in Medicine (DICOM) images produced by medical imaging equipment, including CT scans. OsiriX allows for 2-dimensional viewing and 3-dimen- 
sional rendering of CT scan images. Push cores that were collected from a washover fan (all cores except PC05 and PC09) have CT scans that view the core perpendicular to the long axis of the washover fan and parallel to the long axis of the washover fan. Russian cores and push cores PC05 and PC09 have sagittal and coronal images. CT scans can be downloaded from the data downloads page.

In the PCMSC sediment core lab, push cores were split lengthwise, parallel to the long axis of the washover fan from which they were collected, then photographed and described by using standard sediment logging methods. Push cores were sub-sampled at 1-cm intervals for grain-size analysis. Sample frequencies varied from core to core based on observed lithologic changes. Russian cores were photographed and described after removing tape and plastic wrap from the core. Grain-size analysis was not performed on Russian cores. Core logs including elevations, descriptions, photographs, CT scans, and grain size (push cores only) are available from the associated USGS data release (Bishop and others, 2016; http://dx.doi. org/10.5066/F7PK0D7S).

\section{Grain-Size Analysis}

Samples used for grain-size analysis were placed into a 1,000-milliliter (mL) beaker filled with 200-500 mL of deionized water. Organics were removed by adding 5-10 mL of 30-percent hydrogen peroxide and allowing the sample to oxidize overnight. Following the oxidation, the samples were heated to drive off excess hydrogen peroxide. Samples were then washed twice via centrifugation in order to remove all soluble chemicals and excess organic material. Following washing, the samples were wet sieved to segregate them into three broad size fractions: coarse/gravel ( $>2 \mathrm{~mm})$; intermediate/sand $(2.00 \mathrm{~mm}-0.063 \mathrm{~mm})$; and mud (silt and clay) composed of the material $(<0.063 \mathrm{~mm})$. Sand and gravel fractions were dried in an oven at 80 degrees Celsius $\left({ }^{\circ} \mathrm{C}\right)$ and weighed. Five $\mathrm{mL}$ of Calgon (sodium hexametaphosphate) solution was added to the mud fraction cylinder, and distilled water was added to total the volume to 1 liter (L). The mud + Calgon solution sat overnight to ensure removal of the mud particles' negative charges. Subsequently, a $20-\mathrm{mL}$ aliquot was taken from the 1-L mud fraction to determine the weight of the mud.

The gravel fraction was separated with sieves and binned at 1/4-phi intervals. The sand and mud fractions were analyzed with a Beckman Coulter LS 13-320 laser diffraction particle-size analyzer at 1/4-phi intervals. The particle-size data were then combined and processed with the PCMSC software called pcSDSZ, which determines the particle-size distribution according to graphical statistics using the formulas of Folk and Ward (1957), Folk (1966, 1974), Inman (1952), and Trask (1930 and 1932), as well as moment measures (Collias and others, 1963). The raw grain-size data were also run through the program GRADISTAT (Blott and Pye, 2001) in order to calculate geometric (in metric units) mean, sorting, skewness, and kurtosis of each sample by using the Folk and Ward (1957) method. GRADISTAT also calculates the fraction of sediment from each sample by size category (for example, clay, coarse silt, fine sand) based on a modified Wentworth (1922) size scale. The grain-size analysis outputs from pcSDSZ and GRADISTAT are available from the associated USGS data release (Bishop and others, 2016; http://dx.doi.org/10.5066/F7PK0D7S).

\section{Results}

The sedimentologic characteristics of washover deposits created by storms will reflect the sediment sources that are available for erosion and re-distribution. Sediment samples were collected from a number of potential sources including a beachfront dune (BH15-WP415), the crest of a backbeach berm (BH15-WP416), dune ripples on the lagoon side of the island (BH15-WP106), the swash zone on the lagoon side of the island (BH15-WP107), sand from the beach on the ocean side of the island (BH15-WP427-1), 
beachfront dune soil (BH15-WP427-2), low-tide coarse beach-face sand (BH15-WP448), the lower swash zone on the ocean side of the island (BH15-WP449), the upper swash zone on the beach side of the island (BH15-WP469), the toe of the beach (BH15-WP468), and a low-tide terrace on the beach side of the island (BH15-WP467). Visibly, the sediment sources all looked fairly similar and were composed primarily of a light-colored quartz sand with between 1 and 10 percent darker minerals. Sediment sources range from well-sorted $(1.32$ micrometers $[\mu \mathrm{m}])$ to moderately well-sorted $(1.51 \mu \mathrm{m})$, medium $(327 \mu \mathrm{m})$ to very coarse sand $(665 \mu \mathrm{m})$. The mean grain size of all sediment source samples is $487 \pm 102 \mu \mathrm{m}$, and mean sorting is $1.40 \pm 0.07 \mu \mathrm{m}(\mathrm{n}=12)$.

Identification of HS washover deposits $2 \frac{1}{2}$ years after the event occurred is complicated by the fact that substantial sediment re-working has occurred since the hurricane. Sediment re-working is evident because washover deposits were documented during the field campaign in locations that are visibly not overwashed in aerial imagery collected immediately after the hurricane. Also, aerial imagery from September 2013, 11 months after the hurricane, shows extensive sediment reworking (fig. 5). Elevation data collected in April 2015 indicate that the current ground surface is either higher or lower than the post-hurricane light detection and ranging (lidar) elevation, indicating deposition, erosion, or a combination of the two processes has occurred since the hurricane.

Despite the re-working that has occurred, HS washover deposits are still evident in a number of the trenches and cores. Locations where washover sediment was deposited on a pre-hurricane marsh surface can be identified by using pre- and post-storm aerial imagery. In these locations, HS washover deposits appear as non-laminated gray, tan, or brown sand that sharply contacts the dark gray or black underlying marsh surface. A few samples also have marsh plants bent toward the lagoon (figs. 3 and 6) and (or) lagoonwarddipping foresets (trenches 2 and 3 on transect 1). Sand with faint or sharp horizontal dark mineral laminations above the massive unit may also be a characteristic of HS overwash (figs. 3 and 6). However, because substantial re-working has occurred, it is unknown how much of the above-marsh deposit is from HS and how much occurred in subsequent depositional events (for example, February 2013 Nor'Easter, March 2013

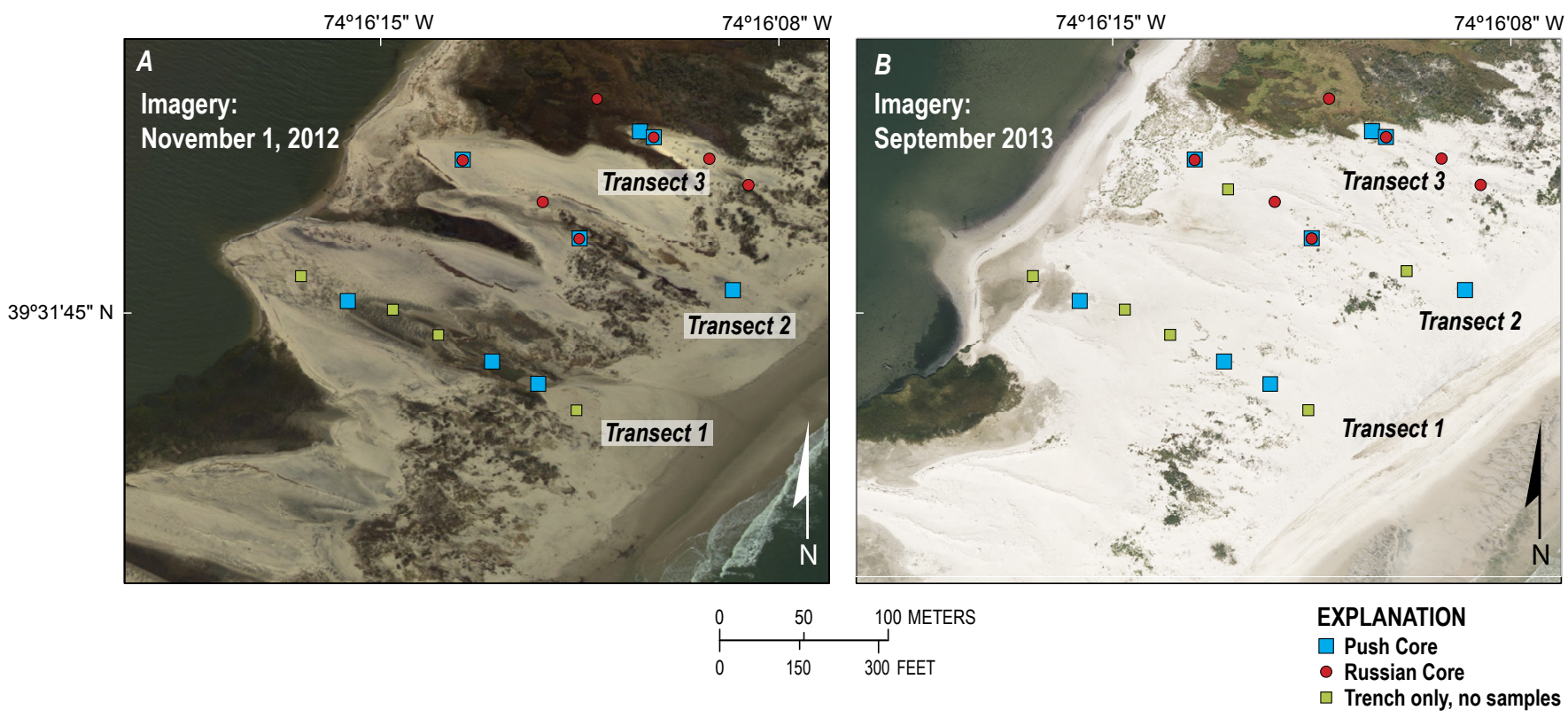

Figure 5. (A) Orthoimagery collected November 6, 2012, showing Hurricane Sandy washover deposits. Note the sharp outlines of the different washover fans. (B) Orthoimagery collected in September 2013 showing the sediment reworking that occurred in the time since Hurricane Sandy sediments were deposited. Imagery from U.S. Geological Survey, 2014. 
Nor'Easter, December 2014 Nor'Easter). Thus, the laminated portion could be a result of depositional processes that occurred after HS.

Push cores PC01, PC02, PC06, PC07, PC10, PC12, and PC13 all have HS washover deposits overlying a pre-hurricane marsh surface. In all these cores, a massive sand ranging in thickness from 4.5 to $19 \mathrm{~cm}$ overlies a pre-hurricane marsh surface. Above the massive sand is a sharply or faintly laminated sand ranging from 6.5 to $30 \mathrm{~cm}$ thick. Total sediment thickness above the pre-HS surface ranges from 13 to $52 \mathrm{~cm}$. Sediment collected from the massive portion of these cores ranges from well-sorted $(1.32 \mu \mathrm{m})$ to moderately wellsorted $(1.54 \mu \mathrm{m})$, medium $(281 \mu \mathrm{m})$ to coarse $(524 \mu \mathrm{m})$ sand. Massive layer mean grain size is $392 \pm 74 \mu \mathrm{m}$, and mean sorting is $1.41 \pm 0.06 \mu \mathrm{m}(\mathrm{n}=13)$. Laminated sediment ranged from well-sorted $(1.34 \mu \mathrm{m})$ to moderately well-sorted $(1.52 \mu \mathrm{m})$, medium $(310 \mu \mathrm{m})$ to coarse $(538 \mu \mathrm{m})$ sand. Laminated layer mean grain

\section{Core ID: $\quad$ BH-15-PC13}

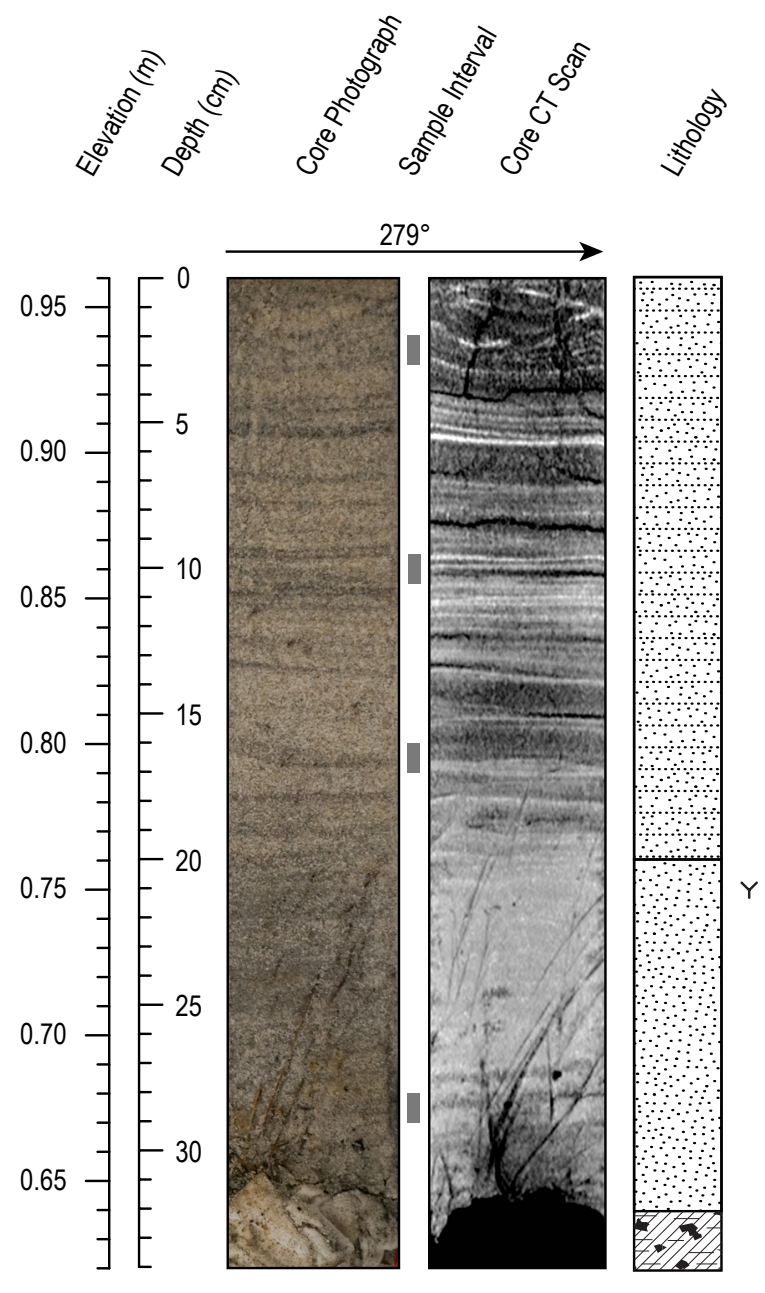

$\begin{array}{llll}\text { Latitude: } & 39.53016 & \text { Elevation: } & 0.96 \mathrm{~m} \\ \text { Longitude: } & -74.26939 & \text { Core Length: } & 34 \mathrm{~cm}\end{array}$

Location: Distal overwash deposit, Beach Haven, CT (Transect 3)
0-20 cm: SAND, $\tan (25 \mathrm{Y} 8 / 1)$, laminated, well-sorted, sub-round, medium sand. Laminations appear sharp near the top though become more faint down section. Laminations are generally horizontal or slightly dipping in the lagoonward direction.
20-32 cm: SAND, gray (GLEY $18 / \mathrm{N})$, massive, well-sorted, sub-round, medium sand. Grass from peat below entrained in the section, many of the grass pieces are bent in the lagoonward direction. Small (2-3 mm length) charcoal pieces present.
32-34 cm: PEAT. This section was lost from the core during recovery, but in the field it was documented that the lost portion was peat. The dark coloration shown in the CT scan image is a rag stuffed in the bottom of the core to prevent movement of the sediment inside the casing.

Figure 6. Photograph and CT scan of push core PC13 showing the massive deposit from Hurricane Sandy at the bottom of the core at a depth of 20-31 centimeters (cm). Dark mineral laminations are visible at depths from 0 to $19 \mathrm{~cm}$. Near the bottom of the core, grasses bent in the lagoonward direction $\left(279^{\circ}\right)$ can be seen in the photograph and the CT scan. The bottom 3-4 cm of the core was lost during core recovery, but the missing portion was identified in the field as a pre-Hurricane Sandy marsh surface; a rag was stuffed in place of the peat to keep the core from sliding inside the casing. 
size is $412 \pm 70 \mu \mathrm{m}$, and mean sorting is $1.41 \pm 0.06 \mu \mathrm{m}(\mathrm{n}=11)$. In cores PC01, PC06, PC12, and PC13, there is a slight coarsening upward in the sediment above the pre-HS marsh surface (fig. 7), and in PC02 and PC07, there is a slight fining upward. The up-core mean grain size in PC10 is erratic and inconclusive.

At the locations where push cores PC03, PC04, and PC08 were collected, the pre-HS surface is sand. Because the pre-hurricane sand and the washover sand are both composed primarily of medium to coarse white quartz grains, it is difficult to determine whether the cores have penetrated the pre-HS surface. A comparison of core elevations to post-HS lidar elevations indicates that these cores may have penetrated HS washover deposits. However, it is also possible that, in the $2 \frac{1}{2} 2$ years between HS and the field campaign, the HS washover deposits were eroded and post-hurricane deposition created the sediment deposits cored during the field study. As such, these cores could be composed of pre-hurricane sediment, hurricane washover sediment, sediment deposited from post-hurricane processes, or some combination thereof. Visibly, two distinct sand units appear to be contained in these cores - a dark brown sand near the bottom of each core and a light tan sand in the upper portion of the cores. The difference in color is likely due to the greater amount of organic matter observed in the darker sediment; grain size is similar between the two units. Sediment in the bottom 6-11 cm of each of these cores consisted of a massive, dark brown, organic-rich sand with a sharp upper contact. This dark brown sand ranged from moderately well-sorted $(1.48 \mu \mathrm{m})$ to wellsorted $(1.39 \mu \mathrm{m})$, medium sand (mean $=440 \pm 31)$. Sediments in the upper $20-35 \mathrm{~cm}$ of these cores consist of light tan to dark brown, massive to laminated, poorly sorted $(2.09 \mu \mathrm{m})$ to well-sorted $(1.33 \mu \mathrm{m})$, medium $(346 \mu \mathrm{m})$ to coarse $(556 \mu \mathrm{m})$ sand. Mean grain size is $436 \pm 68 \mu \mathrm{m}$, and mean sorting is $1.50 \pm 0.22 \mu \mathrm{m}$ $(\mathrm{n}=18)$.

Elevation data from push core PC11 indicate that the sediment contained in the bottom of the core was deposited $36 \mathrm{~cm}$ above the post-hurricane sediment surface; thus, this core does not contain HS washover sediment. Sediment in the core is light tan, is massive or laminated, and exhibits an upcore, repetitive sequence of fining then coarsening. Sediment ranges from poorly sorted $(2.16 \mu \mathrm{m})$ to well-sorted $(1.33 \mu \mathrm{m})$, medium $(331 \mu \mathrm{m})$ to very coarse $(1,030 \mu \mathrm{m})$ sand.

Sediment from the non-vegetated portions of push cores PC05 and PC09, which were collected from areas not overwashed by Hurricane Sandy, ranged from poorly sorted $(2.02 \mu \mathrm{m})$ to well-sorted $(1.409 \mu \mathrm{m})$, fine $(236 \mu \mathrm{m})$ to coarse sand $(542 \mu \mathrm{m})$. Sediment appears primarily massive, though some faint, horizontal laminations are visible in PC05. Shell fragments, up to $2 \mathrm{~cm}$ in diameter, occur throughout PC05. The sandy marsh section of PC09 consists of $10 \mathrm{~cm}$ of poorly to moderately well-sorted (mean sorting $=2.04 \mu \mathrm{m}$ ), very fine to fine (mean grain size $=143 \pm 35 \mu \mathrm{m}$ ) muddy sand and sand. Peat underlies the sandy marsh section, but the core did not penetrate through the peat section, so its thickness is unknown. The peat consisted of poorly sorted $(2.34 \mu \mathrm{m})$, fine muddy sand $(126 \mu \mathrm{m})$ with a dense root mat.

Russian cores were collected from surficial deposits, from the bottom of trenches, and from the bottom of barrier island ponds. Individual cores ranged in length from 28 to $50 \mathrm{~cm}$, though cores combined from a single location totaled up to $200 \mathrm{~cm}$. Sediment in these cores is composed of sand, muddy sand, sandy mud, or peat. Many of the cores contained multiple peat layers, and one core contained five separate peat layers, each separated by a layer of sand (fig. 8). Peat layers ranged from 4 to $24.5 \mathrm{~cm}$ thick, sand layers ranged from 3 to $50 \mathrm{~cm}$ thick, and mud layers ranged from 1.5 to $5 \mathrm{~cm}$ thick.

Based on the presence of a massive sand overlying a marsh surface, HS washover deposits range in thickness from 4.5 to $19 \mathrm{~cm}$ thick. If the laminated portion of the deposit is included as part of the total deposit thickness, HS washover deposit thicknesses may be up to $48 \mathrm{~cm}$. Sedimentologic, stratigraphic, and elevation data collected during this study provide a baseline dataset for future sedimentological and coastal change descriptive and predictive studies and assessments. 


\begin{tabular}{|c|c|c|c|c|c|c|}
\hline \multicolumn{7}{|c|}{ Explanation } \\
\hline \multirow{2}{*}{\multicolumn{2}{|c|}{$\multimap$ Mean grain size }} & $\curvearrowright$ Sorting & 口 & Mud & $\square$ & Medium sand \\
\hline & & & $\theta$ & Very fine sand & $\curvearrowright$ & Coarse sand \\
\hline Core ID: & BH15-PC12 & & $\rightarrow$ & Fine sand & 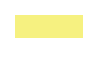 & $\begin{array}{l}\text { Very coarse + } \\
\text { granule sand }\end{array}$ \\
\hline
\end{tabular}
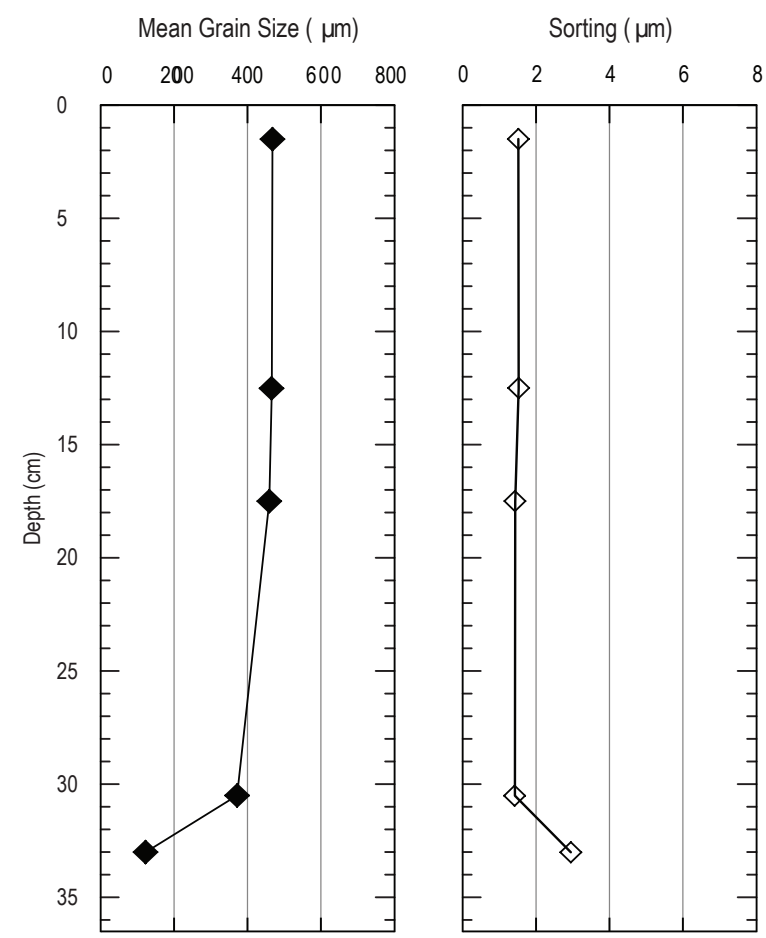

Percent Composition
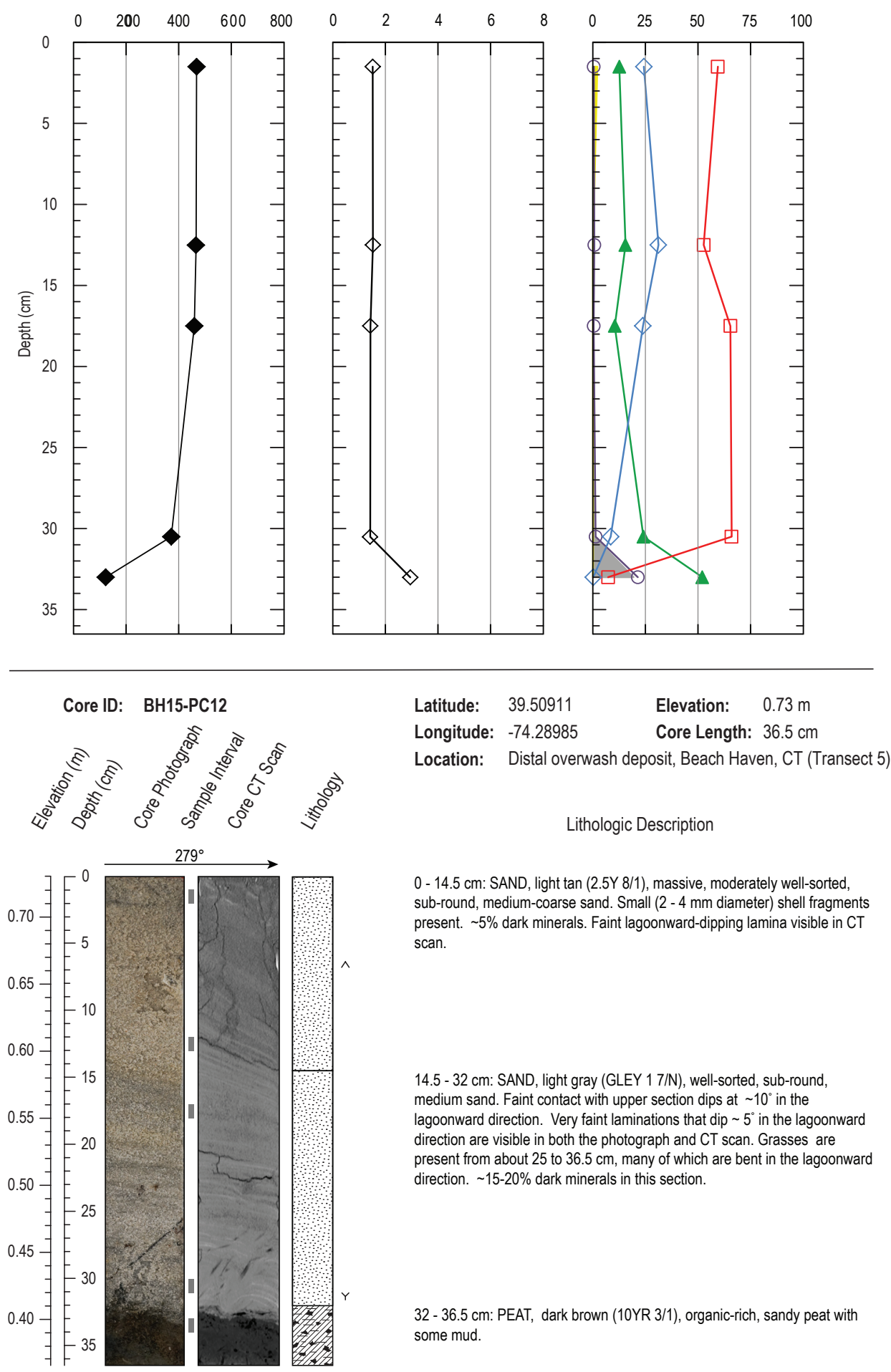

Figure 7. Example of coarsening upward sequence exhibited in sediment above pre-hurricane surface in push core BH15-PC12. 


\section{Core ID: BH15-RC06}

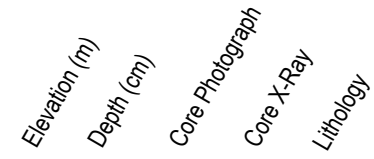

$\begin{array}{llll}\text { Latitude: } & 39.51462 & \text { Elevation: } & 0.31 \mathrm{~m} \\ \text { Longitude: } & -74.28421 & \text { Core Length: } & 200 \mathrm{~cm} \text { (combined) }\end{array}$

Location: Core from pond bottom, Long Beach Island, NJ

Lithologic Description

33-42 cm: PEAT, very dark gray (10YR 3/2), sandy peat with some mud present. Very small ( $1 \mathrm{~mm}$ diameter) shell fragments present. Sand is well sorted, sub-round, medium size.

42-51 cm: SAND, grayish-brown (10YR 5/2), well-sorted, sub-round, non-laminated, medium sand. Very small ( $\sim \mathrm{mm}$ diameter) shell fragments present.

51-61.5 cm: PEAT, very dark gray (10YR 3/1), sandy peat with some mud present. Very small ( $1 \mathrm{~mm}$ diameter) shell fragments present. Sand is well sorted, sub-round, medium size.

61.5-64 cm: SAND, grayish-brown (10YR 5/2), well-sorted, sub-round, non-laminated, medium sand. Very small ( $1 \mathrm{~mm}$ diameter) shell fragments present.

$64-72.5 \mathrm{~cm}$ : PEAT, very dark gray (10YR 3/1), muddy peat with $\sim 10 \%$ well-sorted, sub-round, fine sand. Very small ( $\sim \mathrm{mm}$ diameter) shell fragments present.

72.5-80 cm: SAND, grayish-brown (10YR 5/2), well-sorted, sub-round, non-laminated, medium sand. Very small ( $1 \mathrm{~mm}$ diameter) shell fragments present.

80-86 cm: PEAT, very dark gray (10YR 3/1), muddy peat with $\sim 10 \%$ well-sorted, sub-round, fine sand. Very small ( $1 \mathrm{~mm}$ diameter) shell fragments present.

86-100 cm: SAND, light gray (GLEY1 7/N), well-sorted, sub-round, non-laminated, medium sand. Roots present in top $2 \mathrm{~cm}$ of unit.

100-107 cm: PEAT, very dark gray (10YR 3/1), sandy peat with some mud present. Very small ( $1 \mathrm{~mm}$ diameter) shell fragments present. Sand is well sorted, sub-round, medium size.

107-150 cm: SAND, light gray (10YR 7/1), well-sorted, sub-round, non-laminated, medium sand Lenses $~ 5-10 \mathrm{~mm}$ thick of dark, organic-rich sand occur at 113, 118, and $140 \mathrm{~cm}$.

150-158 cm: organic-rich SAND, very dark gray (10YR 3/1), well-sorted, sub-round, non-laminated, fine sand. Mud, grass, roots, and small ( $1 \mathrm{~mm}$ diameter) shell fragments present.

158-200 cm: SAND, light gray (GLEY1 7/N), well-sorted, sub-round, medium sand. Occasional, faint, 1-2 mm thick, sub-horizontal dark-mineral laminations visible in the core photograph.

Figure 8. Core log for Russian peat auger BH15-RC06, Long Beach Island, New Jersey. 


\section{References Cited}

Bishop, J.M., Richmond, B.M., Zaremba, N.J., Lunghino, B.D., and Kane, H.H., 2016, Hurricane Sandy washover deposit data from southern Long Beach Island, New Jersey_Grain-size, elevations, and graphic core logs: U.S. Geological Survey data release, http://dx.doi.org/10.5066/F7PK0D7S.

Blake, E.S., Kimberlain, T.B., Berg, R.J., Cangialosi, J.P., and Beven, J.L., II, 2013, Tropical cyclone report-Hurricane Sandy: Miami, Fla., National Oceanic and Atmospheric Administration National Hurricane Center, Report AL182012, 157 p. [Also available at http://www.nhc.noaa.gov/data/tcr/AL182012_Sandy.pdf.]

Blott, S.J., and Pye, K., 2001, GRADISTAT - A grain size distribution and statistics package for the analysis of unconsolidated sediments: Earth Surface Processes and Landforms, v. 26, p. 1237-1248.

Collias, E.E., Rona, M.R., McManus, D.A., and Creager, J.S., 1963, Machine processing of geological data: University of Washington Technical Report 87, 119 p.

Folk, R.L., 1966, A review of grain-size parameters: Sedimentology, v. 6, p. 73-93.

Folk, R.L., 1974, Petrology of sedimentary rocks: Austin, Tex., Hemphill, p. 1-159.

Folk, R.L., and Ward, W.C., 1957, Brazos River bar-A study in the significance of grain size parameters: Journal of Sedimentary Petrology, v. 27, p. 3-26.

Henry, D.K., Cooke-Hull, S., Savukinas, J., Yu, F., Elo, N., and Van Arnum, B., 2013, Economic impact of Hurricane Sandy potential-Potential economic activity lost and gained in New Jersey and New York: U.S. Department of Commerce, Economics and Statistics Administration, Office of the Chief Economist. [Also available at http://www.esa.doc.gov/reports/economic-impact-hurricane-sandy.]

Inman, D.L., 1952, Measures for describing the size distribution of sediments: Journal of Sedimentary Petrology, v. 22, p. 125-145.

National Oceanic and Atmospheric Administration, National Ocean Service, National Geodetic Survey, Remote Sensing Division, 2012, Hurricane Sandy-Rapid Response Imagery of the Surrounding Regions, accessed November 5, 2015, at http://storms.ngs.noaa.gov/storms/sandy/.

National Oceanic and Atmospheric Administration, National Geodetic Survey, 2015, CORS Data Products, accessed May 5, 2015, at http://www.ngs.noaa.gov/CORS/data.shtml.

National Oceanic and Atmospheric Administration, National Hurricane Center, 2015, NHC data in GIS formats, accessed October 19, 2015, at http://www.nhc.noaa.gov/gis/.

New Jersey Office of Information Technology, Office of Geographic Information Systems, 2013, 2012 NJ High Resolution Orthoimagery, accessed September 19, 2015, at https://njgin.state.nj.us/NJ_NJGINExplorer/jviewer.jsp?pg=2012_OrthoImagery.

U.S. Geological Survey, Photo Science Inc., 2014, USGS High Resolution Orthoimagery for Edwin B. Forsythe National Wildlife Refuge, New Jersey: 18SWJ625755_201309_0x0500m_4B_1, accessed December 30, 2015, at http://tdds.cr.usgs.gov/metadata/ortho/18S/WJ/18SWJ625755_201309_0x0500m_4B_1.htm.

Trask, P.D., 1930, Mechanical analysis of sediments by centrifuge: Economic Geology, v. 25, p. 581-599.

Trask, P.D., 1932, Origin and environment of source sediments of petroleum: Houston, Texas, Gulf Publishing Company. 
Wentworth, C.K., 1922, A scale of grade and class terms for clastic sediments: Journal of Geology, v. 30, p. 377-392.

Wright, C.W., Fredericks, X., Troche, R.J., Klipp, E.S., Kranenburg, C.J., and Nagle, D.B., 2014, EAARLB coastal topography-Eastern New Jersey, Hurricane Sandy, 2012; first surface (version 1.1, August 18, 2014): U.S. Geological Survey Data Series 767, accessed March 11, 2016, at http://dx.doi.org/10.3133/ds767. 
